\title{
腎移植自験例の臨床成績
}

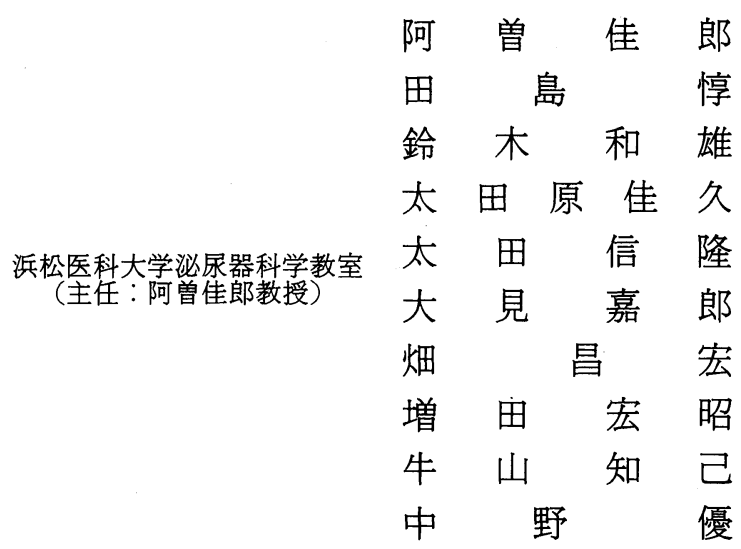

\section{THE CLINICAL RESULT OF RENAL TRANSPLANTATION}

\author{
Yoshio Aso, Atsushi Tajima, Kazuo Suzuki, Yoshihisa Ohtawara, Nobutaka Ohta, \\ Yoshio Ohmi, Masahiro Hata, Hiroaki Masuda, Tomomi Ushiyama and \\ Masaru Nakano \\ Department of Urology, Hamamatsu University School of Medicine \\ (Chairman: Prof. Y. Aso)
}

The clinical result was studied in 33 living and 27 cadaveric renal transplantations performed at our department during the period from November, 1979 to May, 1984.

In living transplantation, the one year survival rates of the patients and the grafts were $89.7 \%$ and $79.9 \%$, respectively. The one year graft survival rate of early 9 cases (LD 1-9) receiving steroides and azathioprine as the immunosuppressants was $55.6 \%$. On the other hand, it has improved to $95.2 \%$ in the recent cases (LD 10-33) after the immunosuppressive method was switched to the main combination of preoperative lymphapheresis, steroids and mizoribine (Bredinin).

In 27 cadaveric transplantations, of which 13 were performed with kidneys imported from the United States (U.S. kidneys) and 14 with domestic kidneys obtained from Shizuoka-ken (domestic kidneys), the one year survival rates of the patients and the grafts were $72.0 \%$ and $53.7 \%$, respectively. When the graft survivals of the U.S. and domestic kidneys were compared, that of the domestic kidneys showed a better result $-75.0 \%$ in contrast to $39.8 \%$ of the U.S. kidneys. From these results, public recognization of the necessity of harvesting domestic kidneys should be urged throughout Japan.

Serious complications, mainly interstitial pneumonia, were mostly observed during the ATN period after cadaveric transplantation.

Obtaining kidneys immediately after the death and finding out the proper immunosuppressive method during the ATN period might be stressed to avoid fatal complications.

要旨：1）浜松医科大学泌尿器科では, 1979年11月から, 1984年 5 月末をでの 4 年半で, 生体腎移植33回, 死体腎移植27回，計60回の腎移植を拈こなった。

2）生体腎移植の 1 年生存率，1 年生着率はそれぞれ $89.7 \% ， 79.9 \%$ あった。しかし，LD 1から LD 9までの初期の症例と, 主としてステロイドを減量し, アザチオプリンに替えて mizoribine を用いて, 術 前リンパ球除去を施行した LD 10以降の症例を比較すると， 1 年生着率に招いて，55.6\%から95.2\% 
向上がみられた。

3）死体腎移植27回のらち，13回が米国輸入腎，14回が国内死体腎によるものであった。死体腎移植の 1 年生存率， 1 年生着率はそれぞれ $72.0 \%, 53.7 \%$ あった。 また，米国輸入腎と国内死体腎を比較す ると， 1 年生着率で，米国輸入腎 $37.8 \%$, 国内死体腎 $75.0 \%$ あったた.

4）合併症では, 特に間質性肺炎が致命的であった。急性尿細管壊死期間中のステロイド増量が致命的 合併症の発症に関与していると考号れた。

\section{1.はじめに}

本邦の血液透析患者数は年々増加しつつあり, 1982 年度の集計では, 約 5 万人となっている1).しかし, 腎 不全の抜本的治療である腎移植は, 本邦においては多 くの努力にもかかわらず，1982年には年間，生体腎移 植245例, 死体腎移植148例, 合計393例に施行されたに すぎない2．

浜松医科大学泌尿器科学教室では, 1979年11月に, 第 1 例目の生体腎移植を施行した. その後, 4 年半経 過した1984年 5 月 31 日現在で, 丁度60回の腎移植（生 体腎移植33回, 死体腎移植27回)を経験した。 以下に, われわれの施行した 60 回の腎移植成績を報告し, 同時 に腎移植成績の向上のための問題点について述べる.

\section{2. 対象书よび方法}

浜松医科大学泌尿器科学教室に打いて施行した生体 腎移植33回, 死体腎移植27回, 合計60回の腎移植を対 象とした，1979年11月より1984年 5 月末まで, 各年度 別の生体拈よび死体腎移植回数は図 1 に示すごとくで ある。

生体腎移植症例の患者内訳は表 1 のごとくである. 生体腎移植症例は全例一次移植であった。性別では男 性 23 例, 女性 10 例であった。腎移植患者の年龄は 10 歳 から48歳に及び，平均 $29 \pm 10$ 歳であった。腎提供者は 母20例, 父 9 例, 同胞 4 例で, 母の場合が多かった. 腎提供者の年齢は，33歳から71歳に及び，平均 $52 \pm 10$

図 1 年度別腎移植施行回数

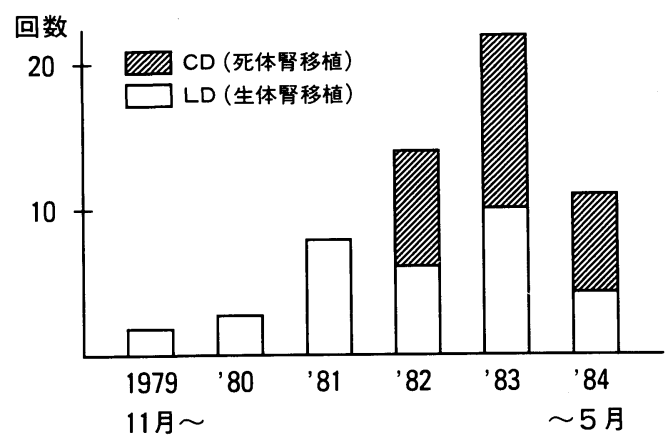

(浜松医科大学泌尿器科)
表 1 生体腎移植症例

\begin{tabular}{|c|c|c|c|c|c|c|c|c|}
\hline 瘭 例 & 性|年 & 年辂 & 霟提 & 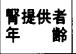 & $\begin{array}{l}\text { HLA A,B locus } \\
\text { 共通抗原数 }\end{array}$ & $\begin{array}{l}\text { HLA DR locus } \\
\text { 共通抗原数 }\end{array}$ & $\begin{array}{l}\text { 拿血糜 } \\
\text { (位) }\end{array}$ & 原 疾 患 \\
\hline LD 1 & 女 & \begin{tabular}{l|l}
45 \\
\end{tabular} & 弟 & \begin{tabular}{|l|}
41 \\
\end{tabular} & \begin{tabular}{|l|}
4 \\
\end{tabular} & 1 & 13 & pyelonephritis \\
\hline 25 & 男 & 41 & 弟 & 33 & 2 & 0 & 6 & CGN \\
\hline 3 & 女 & 19 & 母 & 44 & 3 & 1 & 5 & CGN \\
\hline 45 & 男 2 & 22 & 母 & 51 & 2 & 2 & 5 & CGN \\
\hline 55 & 男 2 & 26 & 父 & 53 & 2 & 1 & 6 & CGN \\
\hline 6 & 女 & 13 & 母 & 40 & 2 & 1 & 10 & CGN \\
\hline 75 & 男 3 & 34 & 母 & 55 & 2 & 1 & 17 & CGN \\
\hline 85 & 男 4 & 47 & 舟 & 71 & 2 & 1 & 3 & CGN \\
\hline 9 & 男 2 & 27 & 母 & 60 & 2 & 1 & 13 & CGN \\
\hline 10 & 男 & 10 & 父 & 37 & 2 & 1 & 111 & CGN \\
\hline $11 \frac{5}{5}$ & 男 3 & 31 & 父 & 56 & 4 & 1 & 11 & CGN \\
\hline 12 & 男 & 37 & 弟 & 33 & 1 & 1 & 12 & CGN \\
\hline 13 & 男 2 & 27 & 母 & 55 & 2 & 2 & 18 & CGN \\
\hline 14 & 女 & 28 & 父 & 58 & 2 & 1 & 39 & CGN \\
\hline 15 & 男 & 23 & 母 & 49 & 2 & 1 & 25 & CGN \\
\hline 16 & 男 & 34 & 母 & 62 & 3 & 1 & 11 & CGN \\
\hline 17 & 男 & 24 & 母 & 51 & 3 & 1 & 3 & CGN \\
\hline 18 & 女 & 15 & 父 & 46 & 2 & 1 & 20 & hypoplastic kidney \\
\hline 19 & 男 & 30 & 父 & 67 & 2 & 1 & 3 & CGN \\
\hline 20 & 男 & 29 & 母 & 51 & 3 & 1 & 17 & CGN \\
\hline 21 & 女 & 18 & 母 & 42 & 2 & 1 & 2 & SLE \\
\hline 22 & 男 & 25 & 母 & 53 & 2 & 1 & 38 & CGN \\
\hline 23 & 男 & 20 & 母 & 44 & 3 & 2 & 32 & hypoplastic kidney \\
\hline 24 & 男 & 27 & 母 & 56 & 2 & 1 & 1 & DM \\
\hline 25 & 女 & 43 & 姉 & 44 & 2 & 0 & 9 & CGN \\
\hline 26 & 男 & 42 & 冓 & 63 & 2 & 2 & 0 & CGN \\
\hline 27 & 男 & 31 & 父 & 57 & 2 & 1 & 13 & CGN \\
\hline 28 & 男 & 38 & 母 & 59 & 2 & 1 & 1 & CGN \\
\hline 29 & 男 & 43 & 母 & 66 & 2 & 2 & 0 & CGN \\
\hline 30 & 男 & 29 & 父 & 57 & 3 & 1 & 54 & CGN \\
\hline 31 & 女 & 15 & 母 & 42 & 2 & 1 & 4 & CGN \\
\hline 32 & 女 & 48 & 母 & 71 & 2 & 2 & 7 & CGN \\
\hline 33 & 女 & 30 & 父 & 55 & 2 & 2 & 2 & CGN \\
\hline
\end{tabular}

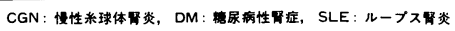

歳であった．組織適合度は表 1 に示すごとく，大部分 の症例で, HLA one haplo-identical であった。腎不 全に至った原疾患は, 低形成腎 2 例, 糖尿病性腎症 1 例，ループス腎炎 1 例，拉よび慢性腎孟腎炎 1 例の他 は, 全例 (28例) 慢性系球体腎炎である. LD 26 とD 29 の 2 症例を除いて, 全例 (31例) 移植前に輸血歴が あった。

一方, 死体腎移植症例の内訳は表 2 のごとくである. CD 14, CD 16, CD 26は二次移植症例である.これら 二次移植 3 例は, 1 回目の生体あるいは死体移植腎が 機能喪失後, 2 回目の移植をうけた症例である。すな わち，CD 14と LD 9, CD 16と CD 5, CD 26と LD 26は それぞれ同一症例である。死体腎移植は, 男性19回, 
表 2 死体腎移植症例

\begin{tabular}{|c|c|c|c|c|c|c|c|c|c|}
\hline $\begin{array}{l}\text { 磻 例 } \\
\text { 号 }\end{array}$ & 性 & 年数 & 㽞提供者 & 湦阻 血 & 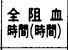 & 零提供者死因 & $\begin{array}{c}\text { HLA A,B locus } \\
\text { 共通抗原数 }\end{array}$ & $\begin{array}{c}\text { HLA DR locus } \\
\text { 共通抗原数 }\end{array}$ & $\begin{array}{l}\text { 会血歴 } \\
(\text { 㱖位 })\end{array}$ \\
\hline $\operatorname{co*} 1$ & 男 & 31 & 28 & 0 & 49 & 頭部外㒇 & 0 & 0 & 20 \\
\hline$* 2$ & 女 & 13 & 39 & 2 & 43 & 動 眽 㾂 & 0 & 0 & 2 \\
\hline$* 3$ & 男 & 36 & 21 & 3 & 46 & 頭部外侮 & 0 & 1 & 2 \\
\hline$* 4$ & 男 & 28 & 65 & 4 & 40 & 漻 & 1 & 1 & 33 \\
\hline$* 5$ & 男 & 31 & 6 ヶ月 & 4 & 60 & 突 然 死 & 0 & 0 & 4 \\
\hline$* 6$ & 男 & 39 & 39 & 11 & 57 & 頭部外侮 & 0 & 0 & 0 \\
\hline$* 7$ & 男 & 33 & 27 & 4 & 50 & 頭部外侮 & 0 & 0 & 3 \\
\hline$* 8$ & 男 & 38 & 40 & 0 & 51 & くも䑏下出血 & 0 & 0 & 2 \\
\hline$* 9$ & 男 & 46 & 23 & 0 & 33 & 交通 故 & 1 & 0 & 4 \\
\hline 10 & 女 & 39 & 64 & 105 & 8 & 小脳出血 & 0 & 不 明 & 10 \\
\hline 11 & 男 & 36 & 64 & 105 & 8 & 小脸出血 & 0 & 0 & 8 \\
\hline 12 & 女 & 26 & 34 & 55 & 6.5 & 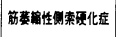 & 不 明 & 不 明 & 7 \\
\hline 13 & 男 & 36 & 34 & 55 & 6.5 & 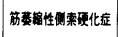 & 不 明 & 不 明 & 2 \\
\hline$* 14$ & 男 & 30 & 10 & 0 & 41 & 交通事故 & 0 & 0 & 28 \\
\hline$* 15$ & 男 & 39 & 16 & 0 & 31 & 交通事故 & 0 & 1 & 24 \\
\hline 16 & 男 & 32 & 57 & 55 & 4 & 頭部外鹪 & 1 & 不 明 & 19 \\
\hline$* 17$ & 男 & 61 & 29 & 12 & 52 & 交 通 故 & 0 & 0 & 12 \\
\hline$* 18$ & 男 & 56 & 19 & 0 & 48 & 頭部外伤 & 0 & 1 & 0 \\
\hline 19 & 女 & 39 & 56 & 59 & 10 & 媨出血 & 不 明 & 不 明 & 4 \\
\hline 20 & 女 & 11 & 56 & 59 & 11 & 脳 出 血 & 不 明 & 不 明 & 23 \\
\hline 21 & 男 & 32 & 40 & 71 & 2 & 莱物アレルキー & 0 & 1 & 2 \\
\hline 22 & 女 & 49 & 45 & 55 & 7 & 脳出, 血 & 1 & 1 & 5 \\
\hline 23 & 女 & 39 & 45 & 55 & 12 & 㜆出 血 & 2 & 1 & 4 \\
\hline 24 & 男 & 34 & 77 & 2 & 3 & くも粠下出血 & 0 & 0 & 6 \\
\hline 25 & 男 & 36 & 77 & 2 & 5 & くも膜下出血 & 1 & 0 & 2 \\
\hline 26 & 男 & 42 & 23 & 5 & 9 & 耓 & 2 & 0 & 24 \\
\hline 27 & 女 & 27 & 23 & 5 & 11 & 自 & 0 & 0 & 9 \\
\hline
\end{tabular}

％米国鍮入督

女性 8 回, 合計 27 回施行された. 患者の年齢は11歳か ら61歳に及び，平均 $36 \pm 11$ 歳であった。 27 例中 13 例は 米国輸入腎による死体腎移植であり，残り14例は，わ れわれが静岡県内で摘出した腎による死体腎移植であ る. 初期の死体腎移植は米国輸入腎によったが, 最近 は全て,われわれが摘出した死体腎による移植である。 死体腎移植の第 1 例目は1982年 4 月に行なわれた。腎 提供者の年齢は， 6 カ月から 77 歳に及び，平均 $39 \pm 20$ 歳であった。 温阻血時間, 全阻血時間は, 表 2 と示す ごとくで，米国輸入腎では，温阻血時間は 0 分から 12 分 (平均 $3 \pm 4$ 分) と極めて短く, 全阻血時間は31時 間から60時間（平均 $46 \pm 9$ 時間）であった。一方，県 内で摘出した死体腎では温阻血時間は 2 分から 105 分 (平均 $49 \pm 34$ 分), 全阻血時間は 3 時間から 12 時間（平 均 $7 \pm 3$ 時間）であった。表 2 と示すごとく，死体腎 移植例では HLA の A, B , DR locus の共通抗原は生 体腎移植例よりも少ない. CD 6と CD 17を除いて全例 (25例)輸血歴を有していた。 また，死体腎移植症例で は, 腎不全に至った原疾患は全て慢性糸球体腎炎で あった。
生体腎提供者の腎摘は, 第11肋骨あるいは第12肋骨 切除を伴った腰部斜切開（側臥位）でおこなわれた。 腎の摘出側の決定については, 両腎間に機能的に差が なければ，腎動脈が 1 本の腎を提供腎とした。左右と も同条件の場合は，原則として左腎を提供腎とした。

米国輸入腎は，全例 beating heart cadaver からの 摘出腎である.摘出腎は細胞内液 (Eurocollins 液) に より灌流された後, 単純冷却下で空輸された ${ }^{3)}$.われわ れが静岡県内で摘出した死体腎は，原則的には藤田ら の方法 ${ }^{4}$ に準じて摘出された。すなわち心停止後, 大腿 動脈より double balloon catheter を挿入し，冷却した 乳酸加リンゲル液による in situ灌流を行ない, evisceration techniqueにより腎摘を行なった。摘出した 腎は単純冷却により, 摘出病院より移植病院へ輸送し た。

腎移植の方法は，通常の手術手技によった ${ }^{5)}$ 。ただ し，左右いずれの提供腎でも，一次移植では全例，患 者右腸骨窩に移植した。したがって二次移植では左腸 骨窩を利用した，膀胱尿管新吻合は，粘膜下トンネル 法によった。また腎動脈が複数の場合は, ex vivo surgery で修復し 1 本の動脈とするか, あるいは異常血管 を外腸骨動脈へ端側吻合した6).

生体腎移植に怙ける免疫抑制法を表 3 に示す。初期 （LD 1 9）の方法と最近の方法（LD 10以降）とは異 なっている.すなわち，初期には主にステロイドとア ザチオプリンによる免疫抑制法を行なったが，最近は ステロイドと mizoribine (商品名 Bredinin) による免 疫抑制法を採用している778)。をた，術前の免疫抑制法 として,われわれが開発したリンパ球除去910)を施行 しているのが大きな特徵である。

死体腎移植に扣ける免疫抑制法を表 4 に示す。生体 腎移植の場合より少ないステロイドの投与量で開始し ている ${ }^{11)}$. 死体腎移植においても, 生体腎移植と同様,

表 3 腎移植に括ける免疫抑制法

〈生体腎〉

\begin{tabular}{|c|c|c|}
\hline & 初期(LD 1 〜9) & 現 在 (LD10 ) \\
\hline predonisolone & $\begin{array}{l}\text { 手術日 } 2 \text { 日前より } \\
120 \mathrm{mg} / \text { 日を漸滅投与 }\end{array}$ & 同 左 \\
\hline methylpredonisolone & $\begin{array}{l}\text { 手術日より } 3 \text { 日間 } \\
1 \mathrm{~g} / \text { 日投与 }\end{array}$ & $\begin{array}{l}\text { 手術日に } \\
1 \mathrm{~g} / \text { 日投与 }\end{array}$ \\
\hline azathioprine & $\begin{array}{l}\text { 手術日 } 2 \text { 日前より } \\
1 \sim 3 \mathrm{mg} / \mathrm{kg} / \text { 日投与 }\end{array}$ & 原則として使わない \\
\hline mizoribine & & $\begin{array}{l}\text { 手術後 } \\
1 \sim 5 \mathrm{mg} / \mathrm{kg} / \text { 日投与 }\end{array}$ \\
\hline ALG & （投与） & （投与） \\
\hline リンパ球除去 & - & 術前に施行 (20回以上) \\
\hline
\end{tabular}


表 4 腎移植に怙ける免疫抑制法

〈死体腎〉

\begin{tabular}{l|l} 
& \\
\hline predonisolone & 手術日より $80 \mathrm{mg} /$ 日を漸隇投与 \\
methylpredonisolone & 手術日に $1 \mathrm{~g} /$ 日投与 \\
azathioprine & ATNによるそ尿期のみ $1 \sim 2 \mathrm{mg} / \mathrm{kg} /$ 日投与 \\
mizoribine & 利尿期より $1 \sim 5 \mathrm{mg} / \mathrm{kg} /$ 日投与 \\
ALG & (投与)
\end{tabular}

浜松医大泌尿器科学教室

原則として mizoribine とステロイドによる免疫抑制 を怙こなった。ただし，急性尿細管壊死 (ATN) では 表 4 亿示すとおり, mizoribine ではなくアザチオプリ ンを投与した. mizoribine は，腎排泄型の薬剤であり， 腎不全に怙ける mizoribine の代謝経路が明らかにさ れていないからである78).

急性拒絶反応の治療法の原則は表 5 に示すごとくで ある. 初期（LD 1 9）の生体腎移植症例と最近（LD 10 以降)の生体腎移植症例では治療法が異なっている. 死体腎移植症例では, 最近の生体腎移植症例と同じ方 法によって急性拒絶反応の治療をおこなった。初期と 最近（死体腎移植症例も含む）とで大きく異なる点は, ステロイドの投与量の違いである。すすおわち初期の生 体腎移植症例では, メチルプレドニン゙ロン 1 日 $1 \mathrm{~g} 3$ 日 間連続投与を招こなったが, 最近（死体腎移植症例も 含む) ではメチルプレドニゾロン $250 \sim 500 \mathrm{mg} /$ 日を 3 〜 4 日間の投与にとどめている。あるいは経口による プレドニゾロンを $200 \mathrm{mg} /$ 日まで増量し，その後漸减し ていった。また最近の症例（死体腎移植症例も含む） では，急性拒絶反応の治療として，ステロイドの増量 が危険と考えられる場合は，表 5 に示すと拈りステロ イドを増量せずに，ALG 投与あるいはリンパ球除去，

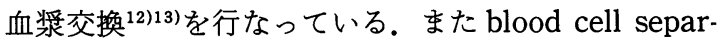
atorを用いてリンパ球除去と血浆交換を連続的に施

表 5 急性拒絶反応時の免疫抑制法

\begin{tabular}{|c|c|c|}
\hline & 初期(LD 1 LD9) & 現在 (LD10 , CD 1 ) \\
\hline methylpredonisolone & $1 \mathrm{~g} /$ 日を 3 日間投与 & $\begin{array}{l}250 \sim 500 \mathrm{mg} / \text { 日を } \\
3 \sim 4 \text { 日間投与 }\end{array}$ \\
\hline predonisolone & 增量せず & $\begin{array}{l}200 \mathrm{mg} / \text { 日に增量 } L \\
\text { 以後漸滅投与 }\end{array}$ \\
\hline 他 & radiation & \begin{tabular}{|l} 
ALG投与 \\
リンパ球除去 \\
血鼎交換 \\
(上記よりいずれが選ぶ)
\end{tabular} \\
\hline & & 浜松医大泌尿器科学教室 \\
\hline
\end{tabular}

行する場合もある.

慢性拒絶反応の治療法は一定せず, 血浆交換, ステ ロイド投与, 無治療等様々であった。

\section{3. 結 果}

1984年 6 月 1 日現在の臨床成績を以下にのべる。

i）生体腎移植症例の生存率括よび生着率（図 2)

生体腎移植 33 症例の 1 年累積生存率は $89.7 \%, 1$ 年 累積生着率は79.9\%である。 2 年累積生存率および生 着率はそれぞれ $89.7 \% ， 74.7 \%$ である。

ii）免疫抑制法の違いによる生体腎移植症例の生着 率 (図 3 )

初期の生体腎移植症例 (LD 1 9) と最近の生体腎移 植症例 (LD 10以降) の移植腎生着率の違いを比較する と図に示すごとくである。

初期怙よび最近の 1 年累積生着率はそれぞれ $55.6 \%$ と $95.2 \%$ である。また 2 年累積生着率では, 初期拉よ

図 2 生体腎移植の果積生存率・生着率（33症例） (1984年 6 月 1 日現在)

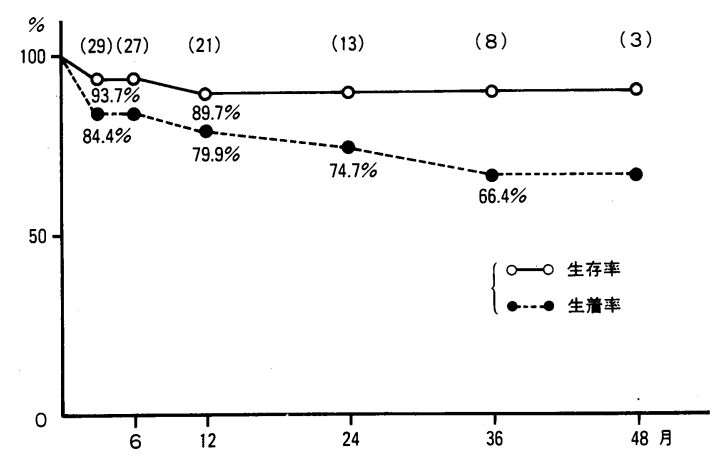

（）内は観察期間に達した症例数を示す

因 3 免疫抑制法の違いによる生体腎移植生着率 （1984年 6 月 1 日現在）

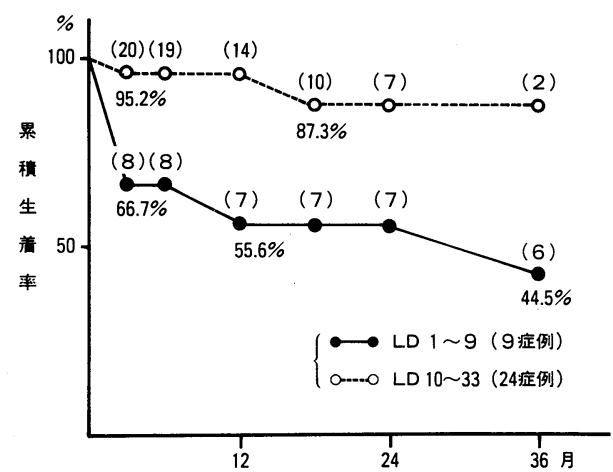

（）内は観察期間に達した症例数を示す 


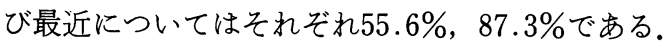

iii）死体腎移植症例の生存率抽よび生着率（図 4)

死体腎移植 27 症例の 1 年累積生存率捛よび 1 年累積 生着率は，それぞれ $72.0 \% ， 53.7 \%$ ぞり，2 年累積 生存率拈よび 2 年累積生着率は，それぞれ $72.0 \%$,

\section{7\%である.}

iv）米国輸入腎，国内死体腎の生着率（図 5 ）

米国輸入腎による移植腎生着率と静岡県内でわれわ れが摘出した死体腎 (国内死体腎) による生着率の違 いを示すと図 5 のごとくなる。

米国輸入腎（13例）の 1 年累積生着率は $37.8 \%$ であ る.一方, 国内死体腎(14例)の 1 年累積生着率は $75.0 \%$ である。

v）拒絶反応

急性拒絶反応の診断は, 臨床所見, 理学的所見, 血 液・尿検查 ${ }^{14)}$, イメージ診断 ${ }^{15}$ 扣よび移植腎生検像によ

図 4 死体腎移植の累積生存率・生着率 (27症例) (1984年 6 月 1 日現在)

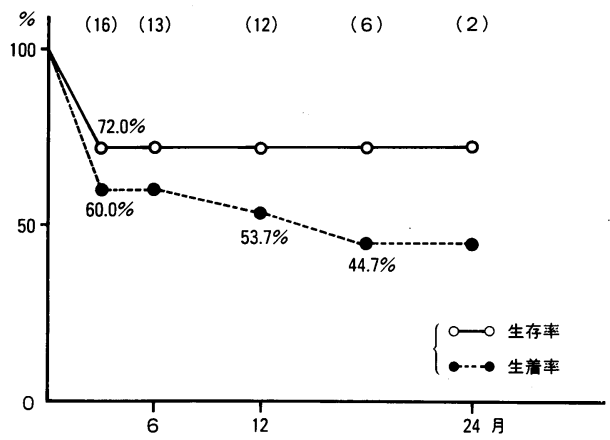

（）内は锶察期間に達した症例数を示す

図 5 米国輸入腎と国内死体腎の生着率比較

（1984年 6 月 1 日現在）

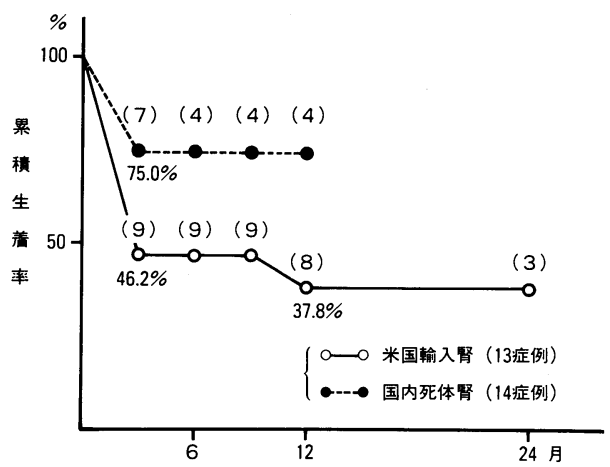

（）内は観察期間に達した症例数を示す
り総合的に行なった。また慢性拒絶反応の診断は主と

して, 臨床経過扣よび移植腎生検像によった。

生体腎移植33症例拉よび死体腎移植27症例の急性拒 絶反応の出現頻度, 移植腎機能の回復の程度は表 6 に 示すごとくである.

慢性拒絶反応は, 生体腎移植 33 症例では 6 例に出現 し，4例はそのまま血液透析に移行した。一方死体腎 移植27症例でも 3 例にみられ, 全例血液透析にもどっ た.

vi）死亡例の検討（表 7)

死亡例は，生体腎移植33例中 3 例 (LD 2, 5,24), 死 体腎移植27例中 8 例 (CD 2, 8, 14, 16, 18, 19, 20, 22)

である. LD 2は ATN 期間中の心不全であり，LD 5は 慢性拒絶反応後維持血液透析にもどり，透析中突然心 停止を扣こし死亡した. 移植後 2 年経過していたが, 死因は不明であった，LD 24は，移植腎機能は良好で あったが, 移植 3 カ月後に重症な糖尿病による心筋障 害のため死亡した。

表 6 急性拒絶反応の頻度と予後

\begin{tabular}{|c|c|c|c|c|c|c|c|}
\hline & & \multirow{2}{*}{ 全症例数 } & \multicolumn{2}{|c|}{ 急性拒䋓反応の頻度 } & \multicolumn{3}{|c|}{ 急性拒絶反応症例の予後 } \\
\hline & & & 症例数 (回数) & $\%$ & 完全回復 & 不完全回復 & 機能衰失 \\
\hline \multirow{2}{*}{ LD } & $1 \sim 9$ & 9 & $7(8)$ & 78 & 5 & 1 & 1 \\
\hline & $10 \sim 33$ & 24 & $9(11)$ & 38 & 8 & 0 & 1 \\
\hline \multirow{2}{*}{$C D$} & 米国輸入腎 & 13 & $7(8)$ & 54 & 4 & 1 & 2 \\
\hline & 国内死体堅 & 14 & $7(7)$ & 50 & 4 & 0 & 3 \\
\hline
\end{tabular}

表 7 死亡症例

\begin{tabular}{|l|l|}
\hline \multicolumn{1}{|c|}{ 症 例 } & \multicolumn{1}{|c|}{ 死 } \\
\hline LD2 & 心不全 \\
\hline LD3 & 原因不明の心停止 \\
\hline LD24 & 心不全(糖尿病による心筋障害) \\
\hline CD2 & 創部出血(移植腎腎門部) \\
\hline CD8 $※$ & 間質性肺炎 \\
\hline$C D 14$ & 自 殺 \\
\hline$C D 16 ※$ & 間質性肺炎 \\
\hline$C D 18 ※$ & 間質性肺炎 \\
\hline$C D 19$ & 消化管出血・敗血症 \\
\hline$C D 20$ & DIC \\
\hline$C D 22 \%$ & 急性膵壊死 \\
\hline
\end{tabular}

※ ステロイド投与増量症例 
$\mathrm{CD} 2$ は移植 1 カ月後, 突然腎門部からの出血のため 死亡した。 CD 8，16抢よび18は，術後 3 カ月以内に全 例間質性肺炎による呼吸不全のため死亡した。いずれ の症例も，臨床経過，検査成績よりサイトメガロウイ ルスによる感染が死因と考えられた，CD 14の死因は 自殺である。本症例の死亡時の移植腎機能は良好で あった。CD 19はATN 期間中に胃潰瘍からの大量出 血が生じ，潰瘍に対し手術を施行したが術後縫合不全 となり, 2 カ月後に敗血症で死亡した。 CD 20は, ATN 期間中であった術後 3 力月目，DICのため死亡した. CD 22は, 移植腎機能は良好であったが, 術後 4 力月目 に急性膵壊死のため死亡した。本症例では血清抗体価, 病理解剖所見から腪壊死の病因は全身性のサイトメガ ロウイルス感染と考兄られた，表 7 に各症例の死因を 示す．死亡例11例中 4 例は，急性拒絶反応の治療とし て用いたステロイドの増量が死因に関与した可能性が 臨床経過より示唆された。

vii）急性尿細管壊死（ATN）

生体腎移植33症例中 2 例 (6.1\%) にATN がみられ た。 2 例とも移植後 10 日以内に血液透析を離脱した。 一方, 死体腎移植 27 症例では全例, ATN のため移植後 6 日から 64 日（平均 $27 \pm 18$ 日）間の血液透析を要した。 な打死体腎移植 27 症例中 7 症例は，ATN 期間中の急 性拒絶反応，あるいは ATN 期間中の死因となった合 併症のため, 血液透析を一度も離脱することができな かった。

表 8 術後合併症（死亡例を除く）

\begin{tabular}{|c|c|c|}
\hline 合 併 症 & 生体腎移植(LD) & 死体腎移植 (CD) \\
\hline ウィルス感染症 & & \\
\hline 帯状疮疹 & $2(4,12)$ & $2(11,17)$ \\
\hline 出血性膀胱炎 & $2(10,18)$ & $13)$ \\
\hline 肝機能障害 & $8\left(\begin{array}{ccc}1, & 6, & 10 \\
11, & 18, & 19 \\
26, & 30,\end{array}\right)$ & $7\left(\begin{array}{ccc}1, & 3, & 4 \\
9, & 11, & 26 \\
27 & \end{array}\right)$ \\
\hline 白血球隇少 & $3(4,9,14)$ & $1(21)$ \\
\hline 消化管出血 & $1(12)$ & $25 \quad$ \\
\hline 動眽吻合部㹟窂 & $1(26)$ & $\longrightarrow$ \\
\hline 糖 尿 病 & $2(8,31)$ & $4\left(\begin{array}{c}1,3 \\
4,23\end{array}\right)$ \\
\hline 大腿骨頭壞死 & $\begin{array}{c}4\left(\begin{array}{c}7,11 \\
15,18\end{array}\right) \\
\text { LD } 7,11,15 \text { は手術 }\end{array}$ & \\
\hline 尿路合併症 & & $\begin{array}{l}\text { 尿管結石 (21) } \\
\text { 尿 管僂 (25) }\end{array}$ \\
\hline
\end{tabular}

（）内は症例番号 viii）その他の合併症

前述の死亡例をのぞいた症例の術後合併症を表 8 に 示す。急性拒絶反応，慢性拒絶反応および ATN につ いてはすでにのべているので, 表 8 にはその他の合併 症をまとめた。

帯状疮疹 ${ }^{16)}$ は, 生体腎移植 2 例, 死体腎移植 2 例の合 計 4 例に出現したが，いずれも完治した。なお 4 例中 2 例に抗ウイルス剤アシクロビルを投与し著効を得て いる。 また出血性膀脱炎 ${ }^{17)}$ は，生体腎移植例では 2 例， 死体腎移植例では 1 例の合計 3 例に認められた。 3 例 とも自然治癒した。

肝機能に関しては，GPT が 1 週間以上にわたって 100 単位以上の高值を示した症例を肝機能障害症例18) と判定した。肝機能障害は，生体腎移植33症例中 8 例 (24.2\%)に，そして死体腎移植27症例中 7 例 $(25.9 \%)$ に出現した。な打肝機能障害の原因は，断定はできな いが臨床所見よりウイルス感染症によるものと推測さ れた. 肝機能障害は, 全例保存的治療により回復した。

末梢血血液像については, 白血球が術後 1 週間以上 にわたって2,000/ $\mathrm{mm}^{3}$ 以下を示した場合白血球減少 と判定した。白血球减少は, 生体腎移植症例 ${ }^{19)}$ では 3

例，死体腎移植症例では 1 例みられた。

消化管出血は生体腎移植 1 例，死体腎移植 1 例でみ られたが，シメチジン投与により治癒した。

動脈吻合部狭窄は生体腎移植症例で 1 例みられた が，この症例では残念ながら移植腎機能の十分な発現 はみられなかった。

インスリン投与を必要とする糖尿病は 6 例（生体腎 移植症例 2 例，死体腎移植症例 4 例）みられた。 6 例 中 5 例はステロイド投与量の減量とともにインスリン 投与を必要としなくなった，残り 1 例は，術後 4 力月 経過しているが，いずれインスリンが不要になると考 えられる。

大腿骨頭壊死は, 生体腎移植33症例中 4 例に認めら れた。 4 例中 3 例は，人工骨頭置換術を施行し，現在 は通常歩行が可能となっている．残り 1 例は軽度の大 腿骨頭壊死であり，現在経過観察中である。

尿路合併症としては, 死体腎移植症例 2 例において, それぞれ移植尿管結石扣よび移植尿管よりの尿瘻がみ られた。いずれも手術により完治し，現在良好な移植 腎機能を保持している。

\section{4. 考察}

慢性腎不全に対する治療である血液透析と腎移植 は，いわば車の両輪である。どちらがよりすぐれてい 
るかを議論することは余り意味のないことである．特 に血液透析は，1970年代より本邦で急速に普及した。 このことが慢性腎不全患者に対して大さな福音を与え たことは事実である。しかし反面，血液透析施行につ いては現在なお大きな制約が付随している。すなわち 血液透析患者に扮いては，時間・場所・食事の制限が 大きな問題である。通常 1 回 5 時間週 3 回の血液透析 は，患者にとって大きな負担である．また，血液透析 患者は水と食塩の制限に多大の配慮が必要である。こ の他に血液透析患者は，負血・高血圧・骨代謝異常・ 性腺機能低下 ${ }^{2021)}$ などの多くの問題をかかえている. これら医学上の問題だけでなく，血液透析については 社会経済上の問題も指摘されている。

移植腎機能が良好に保持されるなら，腎不全患者は 上記の種々の問題から解放される。すなわち，きわめ て質の高い生を享受することが可能となるわけであ る.

現在本邦では，泌尿器科医が腎移植を扣こなってい る施設は限られているが，腎の外科にたずさわる泌尿

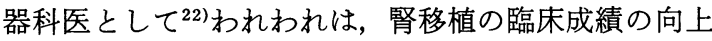
をめざし，1979年11月より積極的に腎移植を施行して きた。

移植開始当初は，まさに試行錯誤であった。腎移植 施行回数 60 回で腎移植開始後 4 年半が経過した.

われわれの移植成績についてみると，生体腎移植 1 年累積生存率扣よび生着率はそれぞれ $93.7 \%$ と $79.9 \%$ であった。な怙日本移植学会の全国集計2)によれば, 生 体腎移植 1 年累積生着率は $74.1 \%$ となっている。

初期の生体腎移植症例（LD 9まで）と最近の生体腎 移植症例 (LD 10以降) は，前述のと招り，免疫抑制法 扣よび急性拒絶反応の治療が異なる。初期の症例怙よ び最近の症例の 1 年累積生着率は，それぞれ $55.6 \%$ と 95.2\%であり, 明らかな改善が認められた。両者間は, いわゆる historical control になり，両者の優劣を一概 に決めつけることはできないが，リンパ球除去と mizoribine を導入した最近の症例で95\%の 1 年累積 生着率が得られるようになったことは事実である。現 在は, 生体腎移植 1 年累積生着率 $100 \%$ を目指す段階に なったと考えられる。

一方, 死体腎移植 27 症例の 1 年累積生存率および 1 年累積生着率は，それぞれ $72.0 \%$ と $55.2 \%$ であった。 日本移植学会の全国集計によれば，死体腎移植 1 年累 積生着率 $38.6 \%$ である。

米国輸入腎3) とわれわれが摘出した国内死体腎に
よる腎移植の 1 年累積生着率は，それぞれ $37.8 \%$ と $75.0 \%$ であった。米国輸入腎は死体腎移植症例の前半 の症例に多く, 国内死体腎は後半の症例に多い。術後 管理等に関する熟練度が，この生着率の差異に関与し ている可能性は否定できないまた，米国輸入腎は全 例 beating heart cadaver からの摘出腎であるが，全 阻血時間は，国内死体腎に比較して長時間となってい る。一方，国内死体腎は原則として心停止後摘出され た腎であるが，米国輸入腎と比較して全阻血時間は短 い.この全阻血時間の差あるいは人種差による組織適 合性の問題等が，米国輸入腎移植と国内死体腎移植の 生着率の差に関与している可能性も十分考えられる。

われわれの死体腎移植成績で反省しなければならな い点は， 1 年累積生存率が $72.0 \%$ であたことである. 特に，ウイルス感染症 (CMV) に起因すると考えられ る死亡例が多かった。死亡例の多くは, ATN 期間中の 合併症によるものであった。間質性肺炎 3 例は全例死 亡したが，急性拒絶反応の治療として用いたステロイ ドの増量が死因に関係していた可能性は否定できな かった。ここに，術後の重篤な合併症の引き金となり らる ATN，あるいは ATN 期間中の適切な免疫抑制 法のあり方について検討すべき由縁が存する.

つまり，移植腎機能が良好であれば，少々過㮃な免 疫抑制のもとでも重篤な合併症が生じることが少ない といらことはよく知られている。しかし, ATN 期間中 は容易に致命的な合併症が生ずることを銘記すべきで あろう。重篤な合併症が生じやすい ATN 期間中の免 疫抑制法をいかに行ならべきかは今後もな和解決すべ き課題として残されるであろう。

また，死戦期あるいは温阻血時間の長い場合は，死 体腎提供者となりえないと考学るべきである。例えば， 自験例の CD 19 と20は同一提供者による死体腎移植で あったが，両症例とも長期の ATN 期間中に重篤な合 併症が生じ (消化管出血, DIC), 死亡した。この死体 腎提供者は死戦期が長時間におよび，また温阻血時間 も長かった。

死体腎移植後 ATN の解決には，脳死による死体腎 摘出の社会的許容が最も重要である．本邦の死体腎移 植成績の向上のために，このことについて地道に努力 する必要がある。しかし，脳死による死体腎摘出が一 般には認められていない現在, 腎保存の問題とともに, ATN 期間中の合併症に対する細心の注意, 迅速な対 策，さらには各疾患の状態に応じた適切な免疫抑制剂 の選択と投与量の設定等の考慮が必要となるであろ 
5.

米国輸入腎がほぼ途絶えつつある現在，死体腎提供 の運動を社会的に，精力的かつ広範にす寸めていかな ければならない，このことが，数少ない本邦の腎移植 症例数を欧米なみの症例数にするための 1 つの鍵 と なっている。

死体腎移植患者生存率は $100 \%$ としなければならな い. 死体腎 1 年累積生着率 $80 \%$ 以上の時代は，すでに 眼前にせまってきている。

\section{5. 結 語}

1979年11月より1984年 5 月までに浜松医大泌尿器科 で行なった生体腎移植33回, 死体腎移植27回, 計60回 の臨床成績について検討した。

生体腎移植については免疫抑制法としてステロイ ド,アザチオプリンを併用していた LD 1９に比較し， リンパ球除去とステロイド, mizoribine (Bredinin)を 主とする抑制法に変更した LD 10 以後の症例では 1 年 生着率は $55.6 \%$ から $95.2 \%$ へと著明な改善がみられ た.

死体腎移植は米国よりの輸入腎13回, 静岡県内より 得られた国内腎14回について 1 年生着率を検討したと ころ，前者は $37.8 \%$ ，後者は $75 \%$ であった。国内より の死体腎の望まれる由縁である。

また，重篤な合併症は死体腎移植の ATN 期間中に みられることが圧倒的に多く，この点からみて，死体 腎提供者よりのすみやかな腎摘出が望をれると共に, 特に ATN 期間中に括ける適切な免疫抑制法について 再考が必要である。

\section{文 献}

1）小高通夫：わが国の透析療法の現況。透析会誌, 16, 367-378, 1983.

2）日本移植学会：1982年度腎移植臨床登録集計報 告. 移植, $18,544-551,1983$.

3）絹川常郎, 岩城裕一, Paul Terasaki, 高橋 寿, 石崎 允，岡崎 肇，関野 宏，高橋公太，東間 紘，太田和夫，山内 潤，大坪 修，稲生網政，渡 久地政夫，宮本克彦，小崎正巳，堀見忠司，阪上賢 一, 折田薰三, 山田宣夫, 打田和治, 高木 弘, 松 浦 治, 小野佳成, 大島伸一, 田島 嵉, 藤田公生, 阿曾佳郎, 有馬正明, 佐川史郎, 園田孝夫：米国上 り輸送された腎臓による死体腎移植42例の検討。 第 2 報一単純冷却腎保存法に関する分析一. 移植, 17, 270-274, 1982.

4）藤田民夫, 浅野晴好, 柳岡正範，玉井秀亀，森口隆 一郎, 置塩則彦, 名出頼男, 神野哲夫, 佐野公彦, 四宮陽一, 宮田隆夫, 大島伸一, 小野佳成, 絹川常
郎, 松浦 治, 打田和治, 富永芳博, 山田宣夫：死 体腎摘出術 6 例の経験-Evisceration Technique について. 移植, 16, 60-66, 1981.

5）阿曾佳郎, 田島 惇：自家腎移植と Bench Surgery. 手術, 35, 31-38, 1981.

6）中野 優, 畑 昌宏, 太田信隆, 鈴木和雄, 田島 惊, 阿曾佳郎：移植腎動脈に対し体外手術を施行 した 7 例。移植，19，374，1984.

7) Tajima, A., Hata, M., Ohta, N., Ohtawara, Y., Suzuki, K. and Aso, Y.: Bredinin treatment in clinical kidney allografting. Transplantation, 38, 116-118, 1984.

8）阿曾佳郎, 田島 惊：新しい移植免疫抑制剂の臨 床応用一ブレディニン．日本臨床，43，136-140， 1985.

9）田島 惊：Lymphapheresis一腎移植の臨床に拧 ける免废抑制の試み。日泌尿会誌, 74, 1098-1112, 1983.

10）田島 惊, 谷口 豊, 増田宏昭, 牛山知巳, 藤井一 彦, 畑 昌宏, 太田信隆, 大見嘉郎, 鈴木和雄, 阿 曾佳郎：腎移植に打ける血液透析回路に連結した blood cell separator の応用一とくに lymphapheresis について一. 透析会誌, 17, 9-14, 1984.

11）大島伸一，小野佳成，絹川常郎，松浦 治，平林 聡, 竹内宣久, 小川洋史, 藤田民夫, 浅野晴好, 梅 田俊一, 杉山 敏: 生体腎移植50例の検討一生存 率の向上について。 日泌尿会誌，74，765-769, 1983.

12）塚田 隆, 田島 惊, 阿曾佳郎：プラスマフェレー シス, 治療への応用一腎疾患一。臨外, 38, 1727-1731, 1983.

13）田島 憞, 塚田 隆, 阿曾佳郎：治療的プラスマ フェレーシスの臨床一腎移植。日本臨床，42, 1900-1904, 1984.

14）太田信隆, 畑 昌宏, 鈴木和雄, 田島 惇, 阿曾佳 郎：尿中イオン化カルシウム值が急性拒絶反応診 断上有用であったと考光られる腎移植症例。日泌 尿会誌，73，211-215，1981.

15）牛山知巳，神林知幸，川守田安彦，太田信隆，大見 嘉郎, 鈴木和雄, 田島 憞, 藤田公生, 阿曾佳郎： 腎移植に打ける超音波断層法の有用性。日泌尿会 誌, 74, 523-528, 1983.

16）畑 昌宏, 太田信隆, 鈴木和雄, 田島 憞, 藤田公 生, 阿曾佳郎：腎移植後帯状疮疹の出現した 1 例. 腎之透析，11，373-376，1981.

17）畑 昌宏, 鈴木俊秀, 牛山知己, 大見嘉郎, 鈴木和 雄, 田島 惊, 藤田公生, 阿曾佳郎：急性出血性膀 胼炎の出現した小児腎移植症例。小児腎不全研究 会誌，1，124-128，1983.

18）横山英二, 熊野弘雄, 真下節夫, 遠藤忠雄, 酒井 紏, 小柴 健：腎移植後の肝障害一特に拒絶反応, 生着率との関係. 日泌尿会誌, 70, 135-143, 1983. 
19）神林知幸, 増田宏昭, 鈴木和雄, 田島 惊, 藤田公 生，阿曾佳郎：腎移植後高度の白血球减少々高熱 が出現した 1 例. 移植，17，439-443，1982.

20）太田信隆, 中野 優, 増田宏昭, 牛山知已, 藤井一 彦, 畑 昌宏, 大見嘉郎, 大田原佳久, 鈴木和雄, 田島 惊, 阿曾佳郎：Bredinin 投与男性腎移植患 者に抢ける性腺機能。移植，19，159-163，1984。
21）田島 嵉, 中野 優, 畑 昌宏, 太田信隆, 鈴木和 雄, 阿曾佳郎：思春期腎移植症例の経過. 思春期医 学, 3, 60-64, 1985.

22）園田孝夫：腎移植の歩みと展望. 日泌尿会誌，74, 1897-1904， 1983.

（1984年11月 14 日受付，特別掲載） 